\title{
DAMPAK ANEMIA KEHAMILAN DENGAN KEJADIAN BAYI BBLR DI PUSKESMAS MUSUK I KECAMATAN MUSUK BOYOLALI TAHUN 2018
}

\author{
The Implication Of Anemia Pregnancy With The Event Of Lbw Baby In \\ Community Health Center Musuk I Kecamatan Musuk \\ Boyolali Year 2018 \\ Sri Suparti ${ }^{1}$, Ani Nur Fauziah ${ }^{2}$ \\ STIKES Mamba'ul 'Ulum Surakarta \\ (srisuparti-dkkby@yahoo.co.id)
}

\begin{abstract}
ABSTRAK
Latar Belakang :Status gizi ibu hamil akan berdampak pada ibu dan janin. Dampak pada ibu antara lain mengalami Kurang Energi Kronik, anemia gizi ibu hamil, bersalin dan nifas. Pada janin akan mengalami gangguan pertumbuhan dan perkembangan antara lain cacat tabung saraf pada janin. Kasus kematian bayi di kabupaten Boyolali tahun 2017 sebanyak 135 kasus ( AKB 9,0/1000 KH), Penyebab kematian bayi karena Berat badan Lahir Rendah sebesar 26,5\%, Kematian bayi di puskesmas Musuk I tahun 2017 sebanyak 5 kasus, 2 diantaranya disebabkan BBLR. Penelitian ini bertujuan untuk mengetahui hubungan anemia ibu hamil terhadap kejadian bayi BBLR di puskesmas Musuk I tahun 2018.

Metode :Penelitian ini menggunakan metode survey analitik dengan pendekatan retrospektif.Penelitian ini menggunakan subyek penelitian karena semua populasi diambil untuk diteliti yaitu semua ibu yang melahirkan BBLR sebanyak 23 orang..Alat pengumpul data berupa master table.Menggunakan data sekunder bersumber dari rekam medik persalinan dan kehamilan.

Hasil :Kasus BBLR di puskesmas Musuk I periode bulan Januari - Juni 2018 sebanyak 23 kasus, dengan rincian 17 kasus (73,91\%) bayi BBLR dan 6 kasus ( 26,09\% ) BBLSR. Ibu yang melahirkan BBLR mayoritas mengalami anemia kehamilan sebanyak 17 responden ( $73,91 \%)$, yang tidak mengalami anemia sebanyak 6 responden ( 26,09\% ).Terdapat hubungan antara anemia ibu hamil terhadap kejadian bayi BBLR dibuktikan dengan uji chi square pada taraf signifikasi 0,050 didapatkan nilai Asymp. Sig. $(2-$ sided $)=0,037<$ dari signifikasi 0,050. Hubungan tingkat sedang dengan hasil coefisien correlation sebesar 0,50.
\end{abstract}

Simpulan:Ada dampak anemia ibu hamil terhadap kejadian bayi berat badan lahirrendah di puskesmas Musuk I tahun 2018.

Kata kunci: Anemia kehamilan, Bayi BBLR 


\begin{abstract}
Background: The nutritional status of pregnant women will have an impact on the mother and fetus. Impacts on mothers include Chronic Energy Deficiency, nutritional anemia in pregnant women, maternity and postpartum. The fetus will experience growth and development disorders including neural tube defects in the fetus. Cases of infant mortality in Boyolali district in 2017 were 135 cases (Infant mortality rate 9.0 / 1000 live births), Causes of infant deaths due to Low Birth Weight of 26.5\%, Infant mortality in Musuk I health center in 2017 were 5 cases, 2 of which were caused LBW. This study aims to determine the relationship of anemia in pregnant women to the incidence of $L B W$ infants in community health center Musuk I in 2018.

Method: This study used an analytical survey method with a retrospective approach. The population of this study were all mothers who gave birth to $L B W$ babies at the Boyolali Musuk I Community health center for the period of January - June 2018 as many as 23 respondents. This study does not use samples but uses research subjects because all populations are taken for research. The data collection tool is a master table. Using secondary data sourced from medical records of labor and pregnancy.

Results: LBW cases in Musuk I community health center for the period of January - June 2018 were 23 cases, with details of 17 cases (73.91\%) of LBW babies and 6 cases $(26.09 \%)$ of $L B W$. The majority of mothers who gave birth to $L B W$ were anemic of pregnancy as many as 17 respondents (73.91\%), those who did not have anemia as many as 6 respondents (26.09\%). There was a relationship between anemia of pregnant women to the incidence of $L B W$ infants as evidenced by the chi square test at significance level 0.050 obtained the value of Asymp. Sig. $(2$-sided $)=0.037<$ from $r$ table 0.050. Medium level relationship with correlation coefficient results of 0.50 .
\end{abstract}

Conclusion: There is a relationship between anemia in pregnant women and the incidence of low birth weight babies in Musuk I community health center in 2018.

Keywords: Anemia of pregnancy, $L B W$ babies

\title{
PENDAHULUAN
}

Status gizi ibu hamil akan berdampak pada ibu dan janin. Dampak pada ibu antara lain mengalami Kurang Energi Kronik ( KEK ), anemia gizi ibu hamil, bersalin dan nifas. Pada janin akan mengalami gangguan pertumbuhan dan perkembangan antara lain cacat tabung saraf pada janin, apabila ibu kekurangan asam folat atau vitamin B9 berupa anenchephalus, memicu terjadinya kelahiran prematur dan bayi berat lahir rendah pada ibu hamil yang mengalami defisiensi zat besi ( Noya A,2016 ). Beberapa keadaan yang dapat menyebabkan kondisi ibu hamil tidak sehat antara lain adalah penanganan komplikasi kurang optimal, anemia pada ibu hamil, ibu hamil yang menderita diabetes, hipertensi, malaria, dan empat terlalu, terlalu muda $<20$ tahun, terlalu tua $>35$ tahun, terlalu dekat jaraknya 2 tahun, dan terlalu banyak anaknya $>3$ orang .( Kemenkes RI, 2016 ) 
Hasil penelitian Ekmawanti tahun 2016 di Puskesmas Tirawuta Kabupaten Kolaka terdapat 39 orang $(42,4 \%)$ mengalami anemia dan yang tidak mengalami anemia sebanyak 53 orang $(57,6 \%)$. Ada hubungan anemia dalam kehamilan dengan kejadian BBLR. Ibu yang mengalami anemia dalam kehamilan berisiko mengalami BBLR sebesar 4,95 kali dibandingkan yang tidak mengalami anemia dalam kehamilan $(p=0,000 ; X 2=12,863 ; O R=4,95 ; C 195 \%=2,013-12,171)$. Hasil penelitian Syifaurrahmah M di RSUD Suliki kabupaten Lima Puluh,hasil analisis bivariat dengan uji Chi Square didapatkan nilai p:0,047 $(\mathrm{p}<0,05)$ dengan rasio prevalensi sebesar 1,7. Disimpulkan bahwa terdapat hubungan bermakna antara anemia pada ibu hamil aterm dengan berat bayi lahir rendah di RSUD Suliki Kabupaten Lima Puluh Kota. Hasil penelitian Novianti Stahun 2015 di di Rumah Sakit Singaparna Medical Centre (SMC) kabupaten Tasikmalaya, hasil penelitian menemukan bahwa sebanyak $8,7 \%$ ibu mengalami anemia dan hasil analisis bivariat dengan uji kai kuadrat mendapatkan nilai $p$ 0,026 yang berarti bahwa anemia ibu hamil berhubungan secara signifikan dengan kejadian BBLR.Penelitian Estiningtyas hubungan Anemia Kehamilan dengan Kejadian Bayi Berat Lahir Rendah di RSUD dr. Moewardi Surakarta. Penelitian terhadap 30 kasus dan 30 kontrol. Sejumlah 19 kasus (31,7 \%) mengalami anemia, diantaranya 15 kasus $(78,9 \%)$ melahirkan bayi BBLR dan 4 kasus $(21,1 \%)$ melahirkan bayi tidak BBLR. Dan terdapat 41 kasus ibu hamil tidak anemia, diantaranya 15 kasus (36,6 \%) melahirkan bayi BBLR dan 26 kasus $(63,4 \%)$ melahirkan bayi tidak BBLR. Terdapat hubungan signifikan antara anemia dalam kehamilan dengan kejadian BBLR di RSUD dr. Moewardi Surakarta $(p=0,002)$ serta ada asosiasi positif antara faktor risiko $(\mathrm{OR}=6,5)$.

Komplikasi kebidanan adalah kesakitan pada ibu hamil, bersalin dan ibu nifas yang dapat mengancam keselamatan jiwa ibu dan janin serta bayinya.Jumlah kasus komplikasi ibu hamil di kabupaten Boyolali tahun 2017 sebanyak 4.466 kasus dari $15.601 \mathrm{ibu}$ hamil. Cakupan penanganan komplikasi kebidanan mencapai seluruh kasus atau 100,0\%. Di puskesmas Musuk I terdapat 89/ 126 kasus ibu hamil komplikasi dari 486 ibu hamil. Kasus komplikasi antara lain penyakit pada ibu antara lain kurang darah atau anemia, tekanan darah tinggi, TBC paru, jantung. Kencing manis dan IMS. Penyakit tersebut menimbulkan masalah baik ibu maupun janin saat kehamilan, persalinan dan nifas. Kasus anemia di puskesmas Musuk I selama tahun 2017 sebanyak 46 kasus atau 9,46\%.( Dinkes Boyolali, 2017 ).

Berdasarkan hasil studi pendahuluan tanggal 21 September 2018 di puskesmas Musuk I,setiap bulan terdapat kurang lebih 126 - $153 \mathrm{ibu}$ hamil yang memeriksakan, dari hasil pemeriksaan ditemukan $9-12$ ibu hamil yang mengalami anemia. Sedangkan ibu yang melahirkan di wilayah puskesmas Musuk I rata-rata sebanyak 41-43 ibu bersalin, dan kejadian BBLR rata-rata 2-4 kasus dari ibu yang menderita anemia, tekanan darah tinggi, kelahiran kembar dan lainnya (Pusk Musuk I, 2018 )

Berdasarkan uraian di atas, maka peneliti tertarik untuk mengetahui "HubunganAnemia Ibu Hamil Terhadap Kejadian Bayi BBLR di Puskesmas MusukI Boyollali tahun 2018. 


\section{METODE PENELITIAN}

Penelitian ini merupakan penelitian surveyanalitik dengan pendekatan retrospektif. Subyek penelitian ini semua ibu yang melahirkan bayi BBLR di wilayah puskesmas Musuk I boyolali berjumlah 23 orang. Penelitian ini menggunakan alat pengumpul data berupamaster table, Metode pengumpulan data yangdigunakan adalah pengumpulan data sekunder. Pengumpulan data sekunder bayi BBLR dilakukan dengan cara melihat dokumen atau catatan yang mendukung data penelitianmeliputi catatan persalinan berupa kartu persalinan, partograf, buku-KIA dan kohort persalinan. Selanjutnya menelusuri data anemia ibu hamil dengan melihat dokumen pemeriksaan kehamilan berupa kartu ANC, buku-KIA dan kohort ibu hamil.Analisa data univariate dengan persentase, untuk analisa data bivariate hubungan anemia ibu hamil terhadap kejadian bayi BBLR dengan menggunakan korelasi chi-square.

\section{HASIL DAN PEMBAHASAN}

\section{Hasil}

Tabel 1 Distribusi Frekwensi Karakteristik Responden Berdasarkan Umur, Pendidikan,Pekerjaan dan paritas

\begin{tabular}{|c|c|c|c|}
\hline $\mathrm{NO}$ & Kelompok Umur & Frekuensi & Persentase \\
\hline 1 & $\leq 20$ tahun & 4 & 17,39 \\
\hline 2 & $21-30$ tahun & 13 & 56,52 \\
\hline \multirow[t]{2}{*}{3} & $31-40$ tahun & 6 & 26,09 \\
\hline & Total & 23 & 100,0 \\
\hline NO & Pendidikan & Frekuensi & Persentase \\
\hline 1 & SD & 2 & 8,59 \\
\hline 2 & SMP & 10 & 43,47 \\
\hline \multirow[t]{2}{*}{3} & SMA & 11 & 47,94 \\
\hline & Total & 23 & 100,0 \\
\hline No & Pekerjaan & Frekuensi & Persentase \\
\hline 1 & Pedagang & 1 & 4,36 \\
\hline 2 & Petani & 14 & 60,86 \\
\hline \multirow[t]{2}{*}{3} & Swasta & 8 & 34,78 \\
\hline & Total & 23 & 100,0 \\
\hline No & Paritas & Frekuensi & Persentase \\
\hline 1. & Primpara & 9 & 39,13 \\
\hline 2. & Multipara & 13 & 56,52 \\
\hline \multirow[t]{2}{*}{3.} & Gerande Multipara & 1 & 4,35 \\
\hline & Total & 23 & 100,0 \\
\hline
\end{tabular}

Berdasarkan Tabel 1. dapat dilihat bahwa menurut karakteristik umur responden mayoritas adalah umur 21 - 30 tahun yaitu 13 orang (56,52\%), menurut karakteristik pendidikan mayoritas adalah berpendidikan SMA yaitu 11 orang (47,94\%),menurut karakteristik pekerjaan mayoritas adalah petani ada 14 orang $(60,86 \%)$, dan menurut paritas mayoritas multiparitas sebanyak 13 orang ( $56,52 \%)$ 
Tabel 2: Distribusi frekuensi variabel ibu hamil yang mengalami anemia dan Bayi BBLRyang lahir di Puskesmas Musuk I Boyolali periode bulan Januari Juni tahun 2018.

\begin{tabular}{clcc}
\hline No & \multicolumn{1}{c}{ Anemia ibu hamil } & Frekuensi & Persentase \\
\hline 1. & Anemia & 17 & 73,91 \\
2. & Tidak anemia & 6 & 26,09 \\
& Total & 23 & 100,0 \\
No & Kejadian Bayi BBLR & Frekuensi & Persentase \\
1. & BBLR & 17 & 73,91 \\
2. & BBLSR & 6 & 26,09 \\
& Total & 23 & 100,0 \\
\hline
\end{tabular}

Tabel 2 diatas menunjukkan bahwa ibu yang melahirkan bayi BBLR mayoritas ibu yang mengalami anemia saat hamil sebanyak 17 responden ( 73,91\% ). Ibu yang tidak mengalami anemia sebanyak 6 responden ( 26,09\%). Adapun kelahiran bayi BBLR di wilayah puskesmas Musuk I periode bulan Januari - Juni 2019 mayoritas BBLR sebanyak 17 responden ( 73,91\% ), yang mengalami BBLSR sebanyak 6 responden ( 26,09\% ).

Tabel 3 HubunganAnemia pada ibu hamil terhadap kejadian bayi BBLR di puskesmas Musuk I Boyolali tahun 2018.

\begin{tabular}{|c|c|c|c|c|c|c|c|}
\hline \multirow{3}{*}{ No } & \multirow{3}{*}{$\begin{array}{c}\text { Katagori } \\
\text { Bayi Berat } \\
\text { Badan lahir } \\
\text { Rendah }\end{array}$} & & & \multicolumn{4}{|c|}{ Anemia Ibu Hamil } \\
\hline & & \multicolumn{2}{|c|}{ BB bayi lahir } & \multicolumn{2}{|c|}{$\mathrm{Ya}$} & \multicolumn{2}{|c|}{ Tidak } \\
\hline & & $\begin{array}{c}\text { Frekue } \\
\text { nsi }\end{array}$ & $\begin{array}{c}\text { Persen } \\
\text { tase }\end{array}$ & $\begin{array}{c}\text { Frekue } \\
\text { nsi }\end{array}$ & $\begin{array}{c}\text { Persent } \\
\text { ase }\end{array}$ & $\begin{array}{c}\text { Frekue } \\
\text { nsi }\end{array}$ & $\begin{array}{c}\text { Persen } \\
\text { tase }\end{array}$ \\
\hline 1. & $\begin{array}{l}\text { BBLR : } \\
1.500-2.499 \\
\text { gr }\end{array}$ & 17 & 73,91 & 12 & 52,17 & 5 & 21,73 \\
\hline \multirow[t]{2}{*}{2.} & $\begin{array}{l}\text { BBLSR : } \\
1.000- \\
1.499 \mathrm{gr}\end{array}$ & 6 & 26,09 & 5 & 21,73 & 1 & 4,37 \\
\hline & Total & 23 & 100,0 & 17 & 73,90 & 6 & 26,10 \\
\hline
\end{tabular}

Berdasarkan tabel 3 diketahui bahwa responden yang melahirkan BBLR sebanyak 17 responden mayoritas mengalami anemia sebanyak 12 orang ( $52,17 \%$ ), Yang tidak mengalami anemia sebanyak 5 orang ( $21,73 \%$ ). Responden yang melahirkan bayi BBLSR sebanyak 6 orang (26,09\%), mayoritas dilahirkan oleh ibu yang menderita anemia sebanyak 5 orang ( $21,73 \%)$, lahir dari ibu yang tidak menderita anemia sebanyak 1 orang $(4,37 \%)$. 
Tabel 4 Analisa Bivariat Chi Square Hubungan Anemia Ibu Hamil Terhadap Kejadian Bayi BBLR di Puskesmas Musuk I tahun 2018.

\begin{tabular}{|c|c|c|c|c|c|}
\hline \multicolumn{6}{|c|}{ Chi-Square Teste } \\
\hline & Value & df & $\begin{array}{l}\text { Asymp.Sig. } \\
\text { (2-sided) }\end{array}$ & $\begin{array}{l}\text { Exact sig. } \\
\text { (2-sided) }\end{array}$ & $\begin{array}{l}\text { Exact sig } \\
\text { (1-sided) }\end{array}$ \\
\hline Pearson Chi-Square & $4.329^{a}$ & 1 & .037 & & \\
\hline Continuity Correction $^{\mathrm{b}}$ & 2.503 & 1 & .114 & & \\
\hline Likelihood Ratio & 6.212 & 1 & .013 & & \\
\hline Fisher's Exact Tes & & & & .058 & .050 \\
\hline Linear-by-linear Assosation & 4.141 & 1 & .042 & & \\
\hline $\mathrm{N}$ of Valid Cases & 23 & & & & \\
\hline
\end{tabular}

a. 2 cells (50,0\%) have expected count less than 5. The minium ecpected count is2.09

b. Computed only for a $2 \times 2$ table

Berdasarkan tabel 4 diketahui hasil koefisien korelasi dengan uji statistik Chi Squaredidapatkan hasilAsymp.Sig ( 2-sided )sebesar 0,037 dengan angka signifikan 0,050. Sehingga hasil Asymp.Sig ( 2-sided) 0,037< dari 0,05/ < dari signifikasi 0,050. Maka $\mathrm{H}_{\mathrm{a}}$ diterima, $\mathrm{H}_{\mathrm{o}}$ ditolak, artinya terdapat hubungan antara anemia ibu hamil terhadap kejadian bayi BBLR di puskesmas Musuk I Boyolali tahun 2018. Hubungan 2 variabel atau coeffisien corelation sebesar 0,50 sehingga terdapat hubungan tingkat sedang.

\section{Pembahasan}

Hasil penelitian pada tabel 1 menunjukkan responden dominanumur $21-30$ tahun sebanyak $14 \mathrm{ibu}(60,86 \%)$. Dengan rincian 11 responden mengalamianemia $(47,82 \%)$ dan 3 responden ( $13,04 \%)$ tidak mengalami anemia.Umur 31 - 40 tahun 6 responden (26,08\%), yang mengalami anemia 3 ibu ( $13,04 \%)$. Umur $\leq 20$ tahun sebanyak 3 reponden ( $17,39 \%)$, semua mengalami anemia. Usia ibu hamil dan melahirkan $\leq 20$ tahun dan $>35$ tahun dikatakan resiko mengalami anemia karena anatomi \& fisiologi siste reproduksi wanita belum sempurna, usia $>35$ tahun secara fisiologis ibu hamil rentang mengalami penyakit kronis ( Chuningham, 2015 ).Pendidikan responden mayoritas SMA sebanyak 11 responden (47,82\%). Dari 11 responden mayoritas mengalami anemia 7 ibu ( 30,43\%), tidak anemia 4 ibu ( 17,39\%). Pendidikan SMP sebanyak 10 responden ( 43,47\%), mayoritas mengalami anemia sebanyak 8responden ( $34,78 \%$ ). Pendidikan SD sebanyak 2 ibu ( $8,69 \%$ ) semua mengalami anemia. Pendidikan yang lebih tinggi lebih mudah dan cepat memahami dan menerapkan pendidikan yang diberikan oleh tenaga kesehatan. Pekerjaan responden mayoritas petani sebanyak 15 responden (65,21\%). Dari 15 responden yang mengalami anemia sebanyak 10 responden $(43,47 \%)$. Pekerjaan petani dominan oleh karena puskesmas Musuk I merupakan daerah pedesaan, Petani merupakan pekerjaan berat, lebih banyak berinteraksi dengan alam.Faktor penyebab anemia antara lain jarak kehamilan yang terlalu dekat, penyakit pada ibu, gangguan pembuluh darah, perokok, pengguna narkoba, peminum dan pekerja berat ( Manuaba, IGB, 2016 ).Paritas responden mayoritas multipara 13 
ibu ( 56,52\%), yang mengalami anemia sebanyak $9 \mathrm{ibu}(39,13 \%)$, tidak anemia 4 ibu ( $17,39 \%$ ). Kondisi anemia dapat meningkatkan resiko kematian ibu pada saat melahirkan, melahirkan bayi dengan berat badan lahir rendah ( BBLR ), janin dan ibu mudah terinfeksi, keguguran dan meningkatkan resiko bayi premature ( Sanjaya, 2011 ). Hasil penelitian ini sesuai dengan hasil penelitian Sanjaya, 2011 tentangprevalensi dan factor rsiko anemia pada WUS di RT miskin kabupaten Tasikmalaya dan Ciamis Jawa Barat tahun 2011 yang menyebutkan paritas multi para yang mengalami anemia 67,24\% ( Sanjaya, 2011 ).

Dari tabel 2 hasil penelitian menunjukkan responden yang melahirkan bayi BBLR dari bulan Januarisampai Juni tahun 2018 sebanyak 23 ibu dengan rincian bayi BBLR $17 \mathrm{ibu}$ ( 73,91\%) dan bayi BBLSR sebanyak 6 ibu ( 26,09\%) dari total 47 kasus bayi BBLR ( 9,97\% dari 471 kelahiran ) tahun 2018 ( Dinkes Boyolali, 2018 ).Frekuensi BBLR dinegara maju berkisar 3,6 - 10,88\%. Hasil penelitian ini sesuai dengan penelitian di negara berkembang berksar 10,0 43,0\%. Ratio BBLR di negara maju dibanding negara berkembang $1: 4$ kasus. Diagnosa BBLR sebelum lahir dengan indikasi pembesaran uterus tidak sesuai dengan usia kehamilan, quickening terjadi lebih lambat, gerakan janin jarang, penambahan berat badan ibu selama hamil lambat. Diagnosa setelah lahir hasil pemeriksaan fisik berat badan kurang ( BBLR ), terdapat tanda-tanda prematuritas ( Mochtar R, 2014 ). Hasil ini relatif sama dengan penelitian Syifaurrahmah M dengan desaincase-control ibuhamilaterm,anemia dan tidakanemia. Analisa bivariat dengan Chi-Square didapatkan hasil p 0,047 ( $\mathrm{p}<0,05)$, Terdapat hubungan yang bermakna antara ibu hamil anemia dengan kejadianbayi BBLR ( Syifaurrahmah, 2013 ). Hasil penelitian Estiningtyas 2016 didapatkan hasil $\mathrm{p}=0,002(\mathrm{p}<0.05)$, Kesimpulan terdapat hubungan yang signifikan antara ibu hamil anemia dengan kejadian bayi BBLR, Ada asosiasi positif( $\mathrm{OR}=6,5)$ Berarti anemia kehamilan meningkatkanresiko bayi BBLR(Estiningtyas, 2016). Hal ini sesuai dengan teori bahwa pengaruh anemia pada janin dan bayi terjadi gangguan dan mengurangi kemampuan metabolisme tubuh sehigga mengganggu pertumbuhan dan perkembangan janin dalam rahim (Waryana, 2010). Prematuritas murni adalah bayi lahir pada usia kehamilan kurang dari 37 minggu dengan berat badan sesuai ( KMK ). Small for date atau bayi kecil untuk masa kehamilan adalah bayi yang berat badannya kurang dari seharusnya umur kehamilan. Dismaturitas adalah sindroma klinik dimana terjadi ketidak seimbangan antara pertumbuhan janin dengan lanjutnya kehamilan. Sehingga bayi yang lahir dengan berat badan tidak sesuai dengan tuanya kehamilan (Mochtar R,2014 ). Hal ini sesuai dengan hasil penelitian Ekmawanti tahun 2016 yang menyatakan ibu yang mengalami anemia dalam kehamilan memiliki resiko melahirkan bayi BBLR sebesar 6, 95 kali dibanding ibu yang tidak anemia ( Ekmawanti, 2016 ). Hasil penelitian ini hampir sama dengan hasil penelitian Andria tentang hubungan ibu hamil dengan kejadian bayi BBLR di RSUD Rokan Hulu tahun 2017 yang menyebutkan persentase bayi BBLR tahun 2017 sebesar 14,9\% ( Andria, 2017)

Hasil penelitian Ekmawati tahun 2016 di Puskesmas Tirawuta Kabupaten Kolaka terdapat 39 orang $(42,4 \%)$ mengalami anemia dan yang tidak mengalami anemia sebanyak 53 orang $(57,6 \%)$. Ada hubungan anemia dalam kehamilan 
dengan kejadian BBLR. Ibu yang mengalami anemia dalam kehamilan berisiko mengalami BBLR sebesar 4,95 kali dibandingkan yang tidak mengalami anemia dalam kehamilan $(p=0,000 ; X 2=12,863 ; O R=4,95 ; C I 95 \%=2,013-12,171)$. Hasil penelitian Syifaurrahmah M di RSUD Suliki kabupaten Lima Puluh, hasil analisis bivariat dengan uji Chi Square didapatkan nilai p:0,047 $(\mathrm{p}<0,05)$ dengan rasio prevalensi sebesar 1,7. Disimpulkan bahwa terdapat hubungan bermakna antara anemia pada ibu hamil aterm dengan berat bayi lahir rendah di RSUD Suliki Kabupaten Lima Puluh Kota. Hasil penelitian Novianti S tahun 2015 di di Rumah Sakit Singaparna Medical Centre (SMC) kabupaten Tasikmalaya, hasil penelitian menemukan bahwa sebanyak $8,7 \%$ ibu mengalami anemia dan hasil analisis bivariat dengan uji kai kuadrat mendapatkan nilai $p$ 0,026 yang berarti bahwa anemia ibu hamil berhubungan secara signifikan dengan kejadian BBLR. Penelitian Estiningtyas tahun 2016 hubungan Anemia Kehamilan dengan Kejadian Bayi Berat Lahir Rendah di RSUD dr. Moewardi Surakarta. Penelitian terhadap 30 kasus dan 30 kontrol. Sejumlah 19 kasus $(31,7 \%)$ mengalami anemia, diantaranya 15 kasus (78,9\%) melahirkan bayi BBLR dan 4 kasus $(21,1$ \%) melahirkan bayi tidak BBLR. Dan terdapat 41 kasus ibu hamil tidak anemia, diantaranya 15 kasus (36,6 \%) melahirkan bayi BBLR dan 26 kasus $(63,4 \%)$ melahirkan bayi tidak BBLR. Terdapat hubungan signifikan antara anemia dalam kehamilan dengan kejadian BBLR di RSUD dr. Moewardi Surakarta $(p=0,002)$ serta ada asosiasi positif antara faktor risiko $(\mathrm{OR}=6,5)$.

Dari tabel 3 didapatkan hasil bayi yang lahir BBLR dengan berat badan lahir $1.500-2.499$ gram sebanyak 17 kasus ( 78,26\% ). Bayi BBLR terlahir dari ibu yang mengalami anemia selama hamil sebanyak $12 \mathrm{ibu}$ ( 52,17\% ). Bayi BBLSR dengan berat badan lahir $1.000-1.499$ gram sebanyak 6 kasus ( 21,74\%). Hasil ini menunjukan peningkatan dari tahun 2017 yang hanya 24 bayi kejadian bayi berat lahir rendah diwilayah Puskesmas Musuk I ( Dinkes Boyolali, 2018 ). Hal ini disebabkan beberapa faktor antara lain status gizi anemia sebelum dan selama hamil dapat mempengaruhi pertumbuhan janin yang sedang dikandung, faktor lainnya adalah penyakit yang berhubungan dengan kehamilan dalam hal ini preeklampsia dan faktor dari bayi yakni kelahiran prematur dan gemelli ( Waryana, 2010 ),sedangkan ibu yang tidak mengalami anemia selama hamil sebanyak 6 ibu (26,10\% ). Bayi BBLSR semua terlahir dari ibu yang mengalami anemia. Faktor penyebab bayi BBLR umur kurang 20 tahun atau lebih 35 tahun. Jarak kehamilan terlalu dekat, penyakit pada ibu seperti hypertensi, jantung, gangguan pembuluh darah, perokok, pengguna narkoba, pekerja berat ( Mochtar $\mathrm{R}, 2014$ ). .Retardasi pertumbuhan janin intra uteri adalah bayi yang lahir dengan berat badan rendah, tidak sesuai usia kehamilan.

Dari tabel 4 analisisa data dengan chi-square ditemukan hasil Asymp. Sig. ( 2-sided ) 0.037 lebih kecil dari signifikasi 0,050. Ha diterima dan Ho ditolak. Harga/ hasil nilai $r$ hitung atau nilai Asymp.sig ( 2-talied $) \leq$ dari nilai signifikasi ( 0,05$)$, maka terdapat hubungan antara anaemia ibu hamil terhadap bayi BBLR ( Ha diterima, Ho ditolak). Sebaliknya tidak ada hubungan antara anemia ibu hamil terhadap bayi BBLR ( Ho diterima, Ha ditolak) bila nilai Asymp.sig ( 2-talied ) > nilai signifikasi $(0,050$ ) ( Sugiyono, 2012 ). Dapat disimpulakan terdapat 
hubungan antara anemia ibu selama hamil terhadap kejadian bayi BBLR di puskesmas Musuk I Boyolali.

Kriteria tingkat hubungan antara anemia ibu saat hamil terhadap kejadian bayi BBLR dengan melihat hasil dari coeffisien correlation antar variabel. Hasil penelitian ini menunjukkan coeffisien correlation sebesar 0,50. Sehingga terdapat hubungan tingkat sedang antara anemia ibu saat hamil terhadap kejadian BBLR di puskesmas Musuk I Boyolali tahun 2018.

Hasil penelitian ini didukung oleh penelitian Noeryasin H, 2013 yang menyebutkan terdapat hubungan antara anemia pada ibu hamil dengan kejadian bayi berat badan lahir rendah di RSUD Raden Mattaher Jambi tahun 2013 ( Noeryasin H, 2013 ). Hasil penelitian ini sejalan dengan penelitian Ekmawanti, 2016 dengan uji statistik chi square didapatkan hasil $p=0,000, X 2=12,863$; $O R=4,95 ; C 195=2,013-12,171$.Ibu yang mengalami anemia dalam kehamilan beresiko mengalami BBLR 4,95 kali dibanding ibu yang tidak mengalami anemia. Hasil penelitian ini juga didukung oleh pemelitian Ine Fitriane, 2017 melalui uji statistik chi square didapatka hasi $p$ : 0,00, sehingga $p<0,05$. Disimpulkan terdapat hubungan antara anemia pada ibu hamil dengan kejadian bayi berat badan lahir rendah di RSUD Kota Bandung ( Fitriane I, 2017 ). Hasil penelitian ini Juga didkung oleh penelitian Ratuh Suci Wijaya. Anaalisa bi-variat dengan chisquaredidapatkan hasil P.value ( $\mathrm{p}=0,026$ ) dan Odds Ratio(OR) $=9,778$. Kesimulan terdapat hubungan antara anemia pada ibu hamildengan kejadian BBLR ( Wijaya RS, 2013 ). Hasil penelitian juga didukung oleh penelitian Andria, 2017 melalui uji statistik chi square didapatkan hasil $P$-value $=0,000$ atau $<0,05$. Disimpulkan terdapat hubungan anemia pada ibu hamil dengan kejadian BBLR di RSUD Rokan Hulu tahun 2017. Hasil penelitian ini juga didukung oleh peneltian Siti Novianti dengan analisis bivariat dengan uji statistik chi square pada derajad kepercayaan $95,0 \%$ didapatkan nilai $p=0,026$ atau $<$ 0,050 . Kesimpulan antara anemia ibu hamil menimbulkan dampak terhadap bayi BBLR ( Novianti, 2015 ).

\section{SIMPULAN DAN SARAN}

\section{Simpulan}

Hasil penelitian menunjukkan kejadian kelahiran BBLR di puskesmas Musuk I Boyolali periode bulan Januari - Juni 2018 sebanyak 23 orang dengan rincian 17 bayi BBLR ( 73,91\%), bayi BBLSR sebanyak 6 ( 26,09\% ). Bayi BBLR dan bayi BBLSR terlahir dari ibu yang mengalami anemia kehamilan sebanyak 17 orang ( $73,91 \%)$, ibu hamil yang tidak mengalami anemia sebanyak 6 orang $(26,09 \%)$. Terdapat hubungan anemia pada ibu hamil terhadap kejadian bayi BBLR dibuktikan dengan analisa bivariat hubungan antar variabel chi squareAsymp. Sig. ( 2-sided ) 0.037 lebih kecil dari nilai signifikasi 0,050. Ha diterima dan $H o$ ditolak. Hasil penelitian ini menunjukkan coeffisien correlation sebesar 0,50. Sehingga terdapat hubungan tingkat sedang antara anemia ibu saat hamil terhadap kejadian BBLR di puskesmas Musuk I Boyolali tahun 2018. 


\section{Saran}

Bagi puskesmas Musuk I, hasil penelitian ini agar dapat digunakan sebagai acuan perencanaan program kesehatan ibu dan anak di waktu mendatang. Memberikan konseling lebih optimal tentang anemia kehamilan untuk menurunkan angka kejadian ibu hamil dengan anemia sehingga kejadian BBLR dapat dicegah. Penemuan kasus dilapangan ditindaklanjuti secara optimal dengan intervensi yang cepat dan tepat khususnya pembiayaan untuk pengadaan makanan tambahan bagi ibu hamil anemia. Bagi nutrisionis lebih optimal dalam memberikan konseling gizi ibu hamil khususnya ibu yang hamil yang mengalami anemia. Bagi bidan lebih teliti dalam melakukan skrening ibu hamil resiko tinggi khususnya anemia agar penatalaksanaan lebih cepat dan tepat.

\section{DAFTAR PUSTAKA}

Andria, 2017; Hubungan Anemia Pada Ibu Hamil Dengan Kejadian Bayi BBLRdi RSUD Rokan Hulu Tahun2017 https://journal.upp.ac.id/index.phn/akb Diakses 22 Oktober 2018 jam 12.0

Cuningham,FG,et,al, 2015; Obstetri William, Jakarta, EGC

Dinkes Jateng, 2017;Profil kesehatan provinsi Jawatengah tahun 2017, https://dinkesjatengprov.go.id Semarang,

Dinkes Boyolali, 2017; Profil kesehatan kabupaten Boyolali tahun 2017,www.boyolali.go.id Boyolali,

Dinkes Boyolali, 2018; Profil kesehatan kabupaten Boyolali tahun 2017, www.boyolali.go.id Boyolali,

Dinkes Jateng, 2017;Buku saku Kesehatan provinsi Jawatengah tahun 2017, https://dinkesjateng.go.id Semarang

Ekmawanti,2016; Hubungan Anemia Dalam Kehamilan Dengan Kejadian Bayi Berat Badan Lahir Rendah di puskesmas Tirawuta Kolaka Timurhttp://repository.poltekkes.kdi.ac.id Diakses 30 Sepptember 2018 jam 12.0

Estiningtyas, 2016;Hubungan antara Anemia dalam Kehamilan dengan Kejadian Bayi Berat Lahir Rendah di RSUD $d r$. Moewardi Surakartahttps://digilib.uns.ac.id/dokumen/download/13940/Mjg2Njc=/Hub ungan-antara-anemia-dalam-keha Diakses 26 Oktober 2018 jam 16.0

Fitriane I, 2017; Hubungan Anemia Pada Ibu Hamil Dengan Kejadian Berat Bayi Lahir Rendah ( BBLR ) di RSUD Kota Bandung http://repository.poltekkesbdg.info/items/browse Diakses 27 Oktober 2018 jam 13.0

Kemenkes RI, 2016; Peraturan Menteri Kesehatan Nomor 39 Tahun 2016; Tentang Pedoman Penyelenggaraan Program Indonesia Sehat Dengan Pendekatan Keluarga. www.depkes.go.id Jakarta

Manuaba,IBG, 2016, Ilmu Kebidanan dan Penyakit Kandungan \& KB untukPendidikan Bidan, Jakarta, EGC

Mochtar,R,2014; Sinopsis Obstetri Fisiologi-Patologi, Jakarta, EGC

Dampak Anemia Kehamilan Dengan Kejadian Bayi BBLR Di Puskesmas Musuk I 
Noya A, 2016; Bayi BBLR di Indonesia https://alodokter.com Diases tgl 19 Oktober 2018 jam 11.15

Noeryasin H, 2013; Hubungan Anemia Ibu Hamil Dengan Kejadian Bayi Berat Badan Lahir Rendah di RSUD Raden Mattaher Jambi Tahun 2013, http://www.academia.edu/34690458. Diakses 14 Oktober 2018 jam 16.0

Novianti S, 2015; Hubungan Anemia pada Ibu hamil dengan Bayi BBLR. http://jurnal.unsil.ac.id/index.php/jssainstek/article/view/440. Diakses 12 Oktober 2018 jam 17.00

Puskesmas Musuk I 2018; Laporan bulanan Program KIA ( LB 3 ) puskesmas MusukI Boyolali

Sanjaya S, 2011; Kemenkes, Jurnal Kesehatan Reproduksi http://ejournal.litbang.depkes,go.id Diakses 21 Oktober 2018 jam 14.00

Sugiyono, 2012: Metode Penelitian Kuantitatif Kualitatif dan $R \& D$, Bandung, Alfa Beta

Syifaurrahmah M, 2017;Hubungan Anemia dengan Kejadian Bayi Berat Lahir Rendah pada Kehamilan Aterm di RSUD Achmad Darwis Suliki. https://www.researchgate.net/publication/42356153 Diakses 17 Oktober 2018 jam 14.0

Waryana. 2010. Gizi Reproduksi. Yogyakarta : Pustaka Rihama

Wijaya R S, 2013; Hubungan Anemialbu Hmil Dengan Kejadian Bayi Berat Badan Lahir Rendah Di RSUD Raden Mattaher Jambi, http://www.academia.edu Diakses 18 Oktober 2018 jam 13.00 